\title{
HUBUNGAN KOMPETENSI GURU TERHADAP PRESTASI BELAJAR SISWA SMP NEGERI 3 TAKKALALLA KABUPATEN WAJO
}

\author{
Aisyah Nursyam \\ Sekolah Tinggi Keguruan dan Ilmu Penddidikan Muhammadiyah Bone, Indonesia \\ e-mail : ichanursyam@gmail.com
}

\begin{abstract}
Abstrak
This study is a correlational study that aims to see the relationship of teacher competency to student achievement in SMP Negeri 3 Takkalalla in the second semester of the 2017/2018 school year in Wajo district. The hypothesis of this study is if H0: There is a significant relationship between teacher competency on student achievement and if H1: There is no significant relationship between teacher competency and student achievement. The data collection technique carried out in this study is a questionnaire that is a list of statements given to other people who are willing to respond according to user requests and documentation to obtain existing data, namely documentation of student grades in the even semester of the 2017/2018 school year and relevant data others. Based on the results of the product moment correlation analysis, the relationship of teacher competence to the learning achievement of students of SMP Negeri 3 Takkalalla in Wajo district obtained a calculated value of -2.59. While the table is 1.66462 at a significant level of $5 \%$ and $N=80$. From the results of the analysis, it can be seen that the calculated value <table $(-2.59<1,99085)$. Based on the analysis, it can be concluded that there is no relationship between teacher competency and student achievement in SMP Negeri 3 Takkalalla district Wajo 2017/2018 Academic Year.
\end{abstract}

Keywords: kompetensi guru, prestasi belajar 


\section{Pendahuluan}

Pendidikan adalah investasi sumber daya manusia jangka panjang yang mempunyai nilai strategis bagi kelangsungan peradaban manusia di dunia. Oleh sebab itu, hampir semua negara menempatkan variabel pendidikan sebagai suatu yang penting dan utama dalam konteks pembangunan bangsa dan negara. Begitu juga Indonesia menempatkan pendidikan sebagai sesuatu yang penting dan utama.

Berdasarkan UUD 1945 Pasal 31 ayat 1 bahwa setiap warga negara berhak mendapatkan pendidikan. Pendidikan merupakan kebutuhan dan hak setiap warga negara. Pendidikan berfungsi untuk mengembangkan kemampuan yang membentuk watak serta peradaban bangsa yang bermartabat dalam rangka mencerdaskan kehidupan bangsa, bertujuan untuk berkembangnya potensi peserta didik agar menjadi manusia beriman dan bertaqwa kepada Tuhan Yang Maha Esa. berakhlak mulia, sehat, berilmu, cakap, kreatif, mandiri, dan menjadi warga negara yang demokratis serta bertanggung jawab.

Salah satu komponen penting dalam pendidikan adalah guru. Peran guru sangat penting karena berfungsi sebagai komunikator yaitu menyampaikan pesan (materi) kepada siswa yang diadopsi sebagai bekal siswa setelah menyelesaikan studinya. Oleh karena itu peranan guru dalam mengajar belum dapat digantikan oleh mesin pengajar, tape recorder dan komputer yang diciptakan oleh manusia, karena alat tersebut tidak dapat menggantikan peranan guru berkenaan dengan unsur-unsur manusiawi seperti sikap, sistem, nilai dan kebiasaan.

Berdasarkan peraturan pemerintah No.19 tahun 2005 tentang Standar Nasional Pendidikan seorang guru harus mempunyai kualifikasi akademik yang dibuktikan dengan sertifikat keahlian yang diperoleh melalui sertifikasi sebagai penguasaan kompetensi. Pada kompetensi kepribadian, setiap guru harus memiliki pribadi yang mantap, stabil, berwibawa, dewasa, arif dan berakhlak mulia. Pada kompetensi profesional, guru dituntut memiliki wawasan keilmuan yang luas dan mendalam, pada kompetensi padagogik, guru dituntut menguasai ilmu pendidikan, antara lain memahami karakter siswa, perancangan pembelajaran, pelaksanaan pembelajaran, evaluasi pembelajaran dan pengembangan peserta didik. Sedangkan pada kompetensi sosial, guru harus mampu berkomunikasi efektif dan bersosialisasi dengan baik. Dalam hal ini kemampuan guru akan menjadi tolak ukur keberhasilan dalam kegiatan belajar mengajar terutama pada mata pelajaran .

Berdasarkan observasi yang dilakukan di SMP Negeri 3 Takkalalla kabupaten Wajo yang dilakukan secara langsung diperoleh gambaran bahwa siswa cenderung bosan untuk belajar. Salah satu penyebabnya adalah penyajian guru yang kurang menarik, guru masih mendominasi kegiatan pembelajaran di kelas sehingga mengakibatkan kecenderungan siswa hanya bersifat pasif.

Keberhasilan suatu proses belajar mengajar sesuai dengan standar Kurikulum Tingkat Satuan Pendidikan (KTSP) sekitar 75\% dari target yang ditetapkan. Mengenai prestasi belajar siswa SMP Negeri 3 Takkalalla sebagai bukti keberhasilan pembelajaran dengan rata-rata 75. Dari data tersebut dapat dikatakan bahwa prestasi belajar siswa SMP Negeri 3 Takkalalla dapat dikategorikan tinggi. Untuk mencapai prestasi yang tinggi tentunya banyak faktor penunjang, seperti intelegensi, kemampuan, kreativitas, kepribadian, nilai dan 
sikap. Oleh karena itu perlu pula diselidiki kompetensi guru yang merupakan salah satu faktor penunjang prestasi belajar .

Untuk mengetahui hubungan kompetensi guru terhadap prestasi belajar bidang studi apapun itu perlu diuji, sehingga persoalan ini layak diadakan penelitian. Oleh karena itu penulis melakukan penelitian dengan judul "Hubungan Kompetensi Guru Terhadap Prestasi Belajar Siswa SMP Negeri 3 Takkalalla kabupaten Wajo.

Adapun tujuan dalam penelitian ini adalah sebagai berikut : (1) untuk mengetahui deskripsi kompetensi guru di SMP Negeri 3 Takkalalla kabupaten Wajo, (2) untuk mengetahui prestasi belajar siswa SMP Negeri 3 Takkalalla kabupaten Wajo, (3) untuk mengetahui hubungan yang signifikan antara kompetensi guru terhadap prestasi belajar siswa SMP Negeri 3 Takkalalla kabupaten Wajo.

Dari hasil penelitian diharapkan dapat memberikan manfaat sebagai berikut: (1) diharapkan dapat menjadi bahan informasi tentang sejauh mana hubungan kompetensi guru terhadap prestasi belajar siswa terutama pada Sekolah Menengah Pertama, (2) diharapkan dapat menjadi landasan penelitian lebih lanjut tentang pada kasus yang relatif sama, dan dapat juga dijadikan sebagai bahan perbandingan kompetensi guru dan prestasi belajar siswa.

\section{Metode Penelitian}

Penelitian ini tergolong penelitian korelasional karena diselidiki keterkaitan antara dua variabel. Dalam penelitian ini, peneliti berusaha menghubungkan suatu variabel dengan variabel lain untuk memahami suatu fenomena dengan cara menentukan tingkat hubungan antara variabel-variabel tersebut. Pengetahuan tentang tingkat hubungan tersebut diharapkan dapat menambah pemahaman tentang faktor-faktor dalam karakteristik yang kompleks dari suatu fenomena seperti prestasi belajar.

Variabel yang digunakan dalam penelitian ini ada dua macam, yaitu variabel $\mathrm{X}$ yang menyatakan kompetensi guru dan variabel $\mathrm{Y}$ yang menyatakan prestasi belajar siswa SMP Negeri 3 Takkalalla kabupaten Wajo. 


\section{Populasi dan Sampel Penelitian}

Populasi dalam penelitian ini adalah seluruh siswa SMP Negeri 3 Takkalalla kabupaten Wajo tahun pelajaran 2017/2018 yang berjumlah 100 siswa.

\begin{tabular}{|c|c|c|c|c|}
\hline No. & Kelas & Laki-laki & Perempuan & Jumlah Siswa \\
\hline 1 & $\mathrm{VII}_{\mathrm{A}}$ & 8 & 12 & 20 \\
\hline 2 & $\mathrm{VII}_{\mathrm{B}}$ & 10 & 13 & 23 \\
\hline 3 & VIII & 13 & 15 & 28 \\
\hline \multirow[t]{2}{*}{4} & IX & 18 & 11 & 29 \\
\hline & Jumlah & 49 & 51 & 100 \\
\hline
\end{tabular}

Menurut Sugiyono (2011: 62) sampel adalah bagian dari jumlah dan karakteristik yang dimiliki oleh populasi. Pengambilan sampel dalam penelitian ini dengan teknik probability sampling dengan menggunakan proportional simple random sampling. Probability teknik pengambilan sampel yang memberikan peluang yang sama bagi setiap unsur (anggota) populasi untuk dipilih menjadi anggota sampel dari populasi dilakukan secara acak tanpa memperhatikan strata yang ada dalam populasi itu (Sugiyono 2001: 63-64).

Besarnya sampel dalam penelitian ini ditentukan dengan rumus Slovin dengan pertimbangan bahwa populasi relatif homogen sehingga tidak terlalu diperlukan untuk distratifikasi. Selain itu, penggunaan rumus ini akan menghasilkan jumlah sampel yang relatif lebih besar dibanding beberapa rumus lain, sehingga karakteristik dari populasi akan lebih terwakili.

Rumus selengkapnya sebagai berikut:

$$
\begin{aligned}
& \mathrm{n}=\frac{\mathrm{N}}{1+\mathrm{Ne}^{2}} \\
& \begin{array}{ll}
\text { dimana: } \\
\mathrm{n}= & \text { ukuran sampel } \\
\mathrm{N}= & \text { ukuran populasi } \\
\mathrm{e}= & \text { persen kelonggaran ketidaktelitian karena kesalahan pengambilan } \\
& \text { yang masih ditolerir atau diinginkan misalnya 2\% (Budi Koestoro } \\
\quad \text { dan Basrowi 2006: } 250 \text { ) }
\end{array} \\
& \text { Populasi 100 siswa dan tingkat signifikansi 0,05, maka besarnya sampel }
\end{aligned}
$$
pada penelitian ini adalah:

$$
\begin{aligned}
& \mathrm{n}=\frac{\mathrm{N}}{1+\mathrm{Ne}^{2}} \\
& \mathrm{n}=\frac{100}{1+100.0,05^{2}} \\
& \mathrm{n}=\frac{100}{1+100 .(0,0025)} \\
& \mathrm{n}=\frac{100}{1+0,25} \\
& \mathrm{n}=\frac{100}{1,25} \\
& \mathrm{n}=80
\end{aligned}
$$


Untuk lebih jelasnya keadaan sampel dalam penelitian ini dapat dilihat pada tabel berikut:

Tabel 3.2 Keadaan Sampel Penelitian

\begin{tabular}{cccc}
\hline Kelas & Laki-laki & Perempuan & Jumlah Sampel \\
\hline VII $_{B}$ & 10 & 13 & 23 \\
VIII & 13 & 15 & 28 \\
IX & 18 & 11 & 29 \\
\hline Jumlah & 41 & 39 & 80 \\
\hline
\end{tabular}

Sumber : SMP Negeri 3 Takkalalla

\section{Instrumen Penelitian}

Instrumen atau alat pengumpulan data yang akan digunakan dalam penelitian ini yaitu angket (kompetensi guru) dan dokumentasi (prestasi belajar siswa/nilai akademik).

1. Angket

Angket adalah daftar pernyataan yang diberikan kepada orang lain yang bersedia memberikan respon sesuai dengan permintaan pengguna. Tujuan penyebaran angket ialah mencari informasi yang lengkap mengenai suatu masalah dan responden tanpa rasa khawatir bila memberikan jawaban yang tidak sesuai dengan kenyataan dalam pengisian daftar pernyataan. Angket yang digunakan untuk mengukur kompetensi guru. Angket bertujuan untuk mengetahui respon dan kesan siswa terhadap guru bidang studi .

Tabel 3.3 Kategori Kompetensi Guru

\begin{tabular}{|c|c|}
\hline Skala & Kategori \\
\hline $\mathrm{X}<(\mathrm{M}-\mathrm{SD})$ & Rendah \\
\hline$(\mathrm{M}-\mathrm{SD}) \leq \mathrm{X}<(\mathrm{M}+\mathrm{SD})$ & Sedang \\
\hline$(\mathrm{M}+\mathrm{SD})<\mathrm{X} \leq$ skor maksimal & Tinggi \\
\hline
\end{tabular}

Sumber: (Lisa Wahyuni, 2015: 45)

Keterangan:

$\mathrm{M} \quad=$ Mean (Rata-rata)

$=\frac{\text { (Skor tertinggi }+ \text { skor terendah }}{2}$

$\mathrm{SD}=$ Standar Deviasi

$=\frac{\text { (Skor tertinggi-skor terendah }}{6}$

a. Kisi-kisi Instrumen Kompetensi Guru

Tabel 3.4 Kisi-kisi Instrumen Kompetensi Guru

\begin{tabular}{|c|c|c|c|}
\hline Indikator & Sub Indikator & $\begin{array}{c}\text { Item } \\
\text { Positif }\end{array}$ & $\begin{array}{c}\text { Item } \\
\text { Negatif }\end{array}$ \\
\hline \multirow{4}{*}{$\begin{array}{l}\text { a. Kompetensi } \\
\text { Kepribadian }\end{array}$} & 1. Kepribadian yang mantap dan stabil & 1 & 2 \\
\hline & 2. Kepribadian yang dewasa & 3,4 & 5 \\
\hline & $\begin{array}{l}\text { 3. Kepribadian yang arif dan } \\
\text { berwibawa }\end{array}$ & $6,7,8$ & \\
\hline & 4. Berakhlak mulia dan dapat menjadi & 9 & 10 \\
\hline
\end{tabular}


teladan

b. Kompetens Sosial

1. Mampu berkomunikasi dan bergaul

11,12

13,14 , secara efektif dengan peserta didik

2. Mampu berkomunikasi dan bergaul secara efektif dengan sesama pendidik dan tenaga kependidikan

3. Mampu berkomunikasi dan bergaul secara efektif dengan orang tua atau wali siswa peserta didik dan masyarakat sekitar

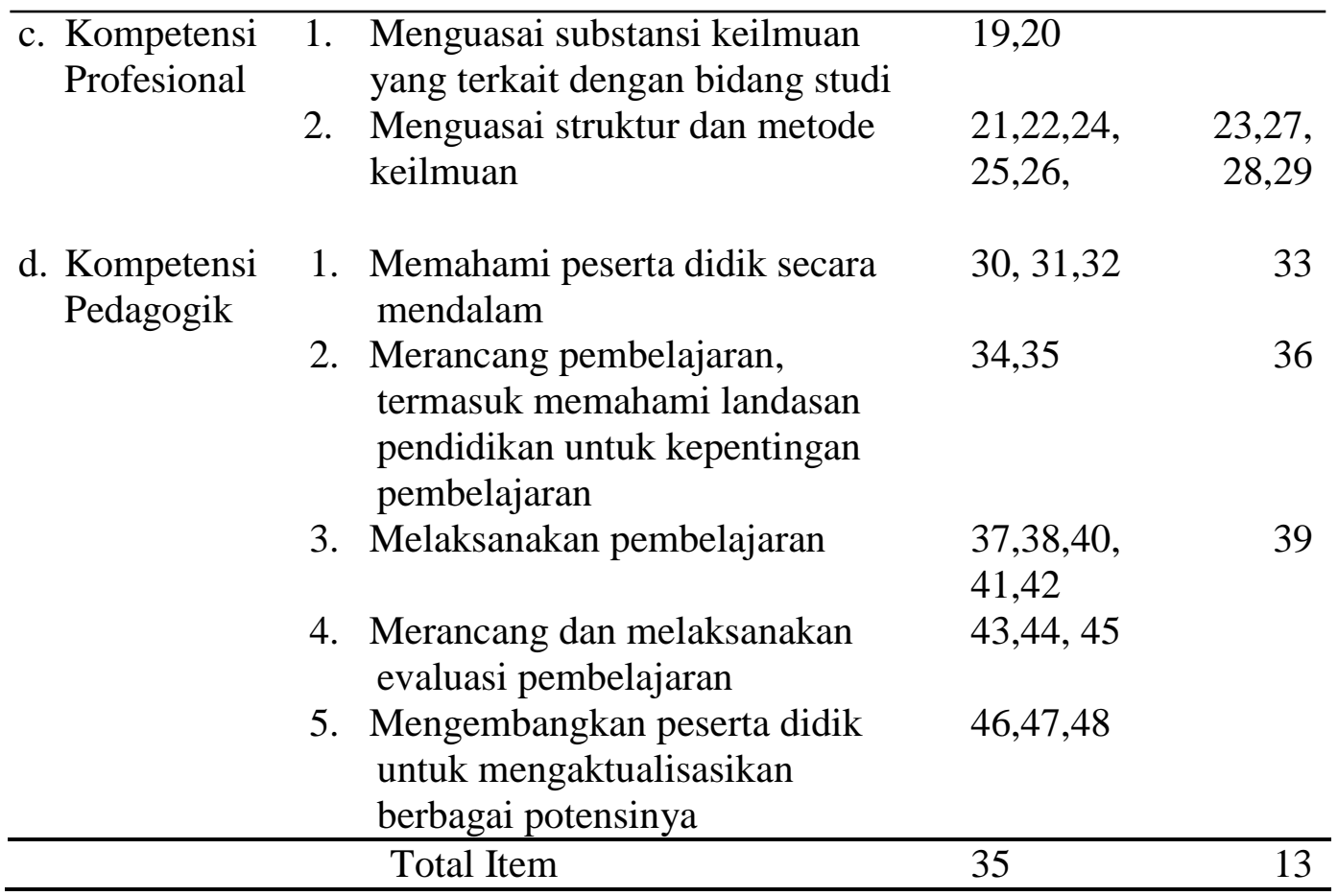

Sumber: Kunandar 2007

Uji Validitas dan Reabilitas Angket

a. Uji Validitas Ahli

Sebelum peneliti melakukan uji instrumen, terlebih dahulu peneliti melakukan uji validasi oleh ahli. Uji validasi dilakukan oleh dosen pembimbing.

Berdasarkan tabel, diketahui jumlah rata-rata untuk kedua validator adalah 6,8, jika dibagi dua maka didapatkan hasil sebesar 3,4. Nilai $2,5 \leq 3,4 \leq$ 3,5 yang berarti angket tersebut dinyatakan sahih.

b. Uji Validitas Item

Uji validitas dilakukan dengan bantuan program SPSS 24. Teknik pengujian yang digunakan Bivariate Pearson (Produk Momen Pearson.Angket kompetensi guru terdiri dari 48 item pernyataan, setelah divalidasi jumlah item yang valid sebanyak 31 item dan tidak valid sebanyak 17 item. 
c. Uji Reabilitas

Hasil pengukuran konsisten jika dilakukan pengukuran berulang. Untuk mencapai hal tersebut dilakukan uji reabilitas dengan menggunakan SPSS 24. Berikut hasil uji reabilitas instrumen kompetensi guru.

Tabel 3.8 Hasil Uji Reabilitas Kompetensi Guru

Reliability Statistics

\begin{tabular}{rrrr}
\hline Cronbach's Alpha & N of Items & \\
\hline & 1.000 & & 48 \\
\hline
\end{tabular}

Berdasarkan hasil perhitungan tersebut, nilai Cronbach Alpha > 0,7. Dengan kompetensi guru $1>0,7$ maka instrumen tersebut dinyatakan reliabel.

2. Dokumentasi

Dokumentasi ditujukan untuk memperoleh data yang telah ada yaitu dokumentasi nilai rapor semester genap tahun pelajaran 2017/2018 dan data yang relevan lainnya.

Tabel 3.9 Kategori Prestasi Belajar

\begin{tabular}{|c|c|}
\hline Skor & Kategori \\
\hline $81-100$ & Sangat Baik \\
\hline $61-80$ & Baik \\
\hline $41-60$ & Cukup \\
\hline $21-40$ & Kurang \\
\hline $0-20$ & Sangat Kurang \\
\hline
\end{tabular}

Sumber: Depdikbud dalam (Usman,2008: 26)

\section{Teknik Pengumpulan Data} berikut :

Untuk memperoleh data dalam penelitian ini digunakan teknik sebagai

1. Angket : Teknik ini digunakan untuk mengetahui kompetensi guru mengajar di depan setiap siswa dalam pelajaran. Angket kompetensi guru terdiri atas beberapa pernyataan. Butir angket dinyatakan dalam 2 bentuk, yaitu pernyataan yang bersifat positif dan pernyataan yang bersifat negatif. Hal ini untuk menghindari jawaban yang asal memilih.

2. Dokumentasi: Teknik ini dilakukan untuk memperoleh data tentang nilai prestasi belajar yang diperoleh dari nilai rapor semester genap tahun pelajaran 2017/2018 SMP Negeri 3 Takkalalla.

\section{Teknik Analisis Data}

Dalam penelitian ini data dianalisis dengan menggunakan serangkaian pengujian statistik antara lain sebagai berikut:

\section{Uji Prasyarat}

\section{a. Uji Normalitas}

Dalam penelitian ini, pengujian normalitas yang digunakan adalah metode chi-kuadrat yang bertujuan untuk mengetahui data yang diteliti berdistribusi normal atau tidak. Uji normalitas dilakukan pada kedua variabel yang akan diteliti. Uji normalitas pada penelitian ini menggunakan bantuan program SPSS 24 dengan rumur kolmogorof-Smirnov dengan ketentuan pengujian 
dengan taraf signifikan $5 \%$

$\mathrm{H}_{0}$ : Angka signifikan uji kolmogorof-Smirnov sig>0,05 menunjukkan data berdistribusi normal

$\mathrm{H}_{1}$ : Angka signifikan uji kolmogorof-Smirnov sig $<0,05$ menunjukkan data tidak berdistribusi normal

\section{b. Uji Linearitas}

Uji linearitas digunakan untuk mengetahui apakah hubungan antara setiap variabel bebas dan terikat dalam penelitian bersifat linear atau tidak secara signifikan. Data dikatakan linear jika sig $>0,05$. Perhitungan dilakukan melalui program SPSS 24.

1. Uji Hipotesis

a. Korelasi Product Moment yaitu sebagai berikut :

$$
\mathrm{r}_{\mathrm{xy}}=\frac{\mathrm{xy}-\frac{\left(\sum \mathrm{x}\right)\left(\sum \mathrm{y}\right)}{\mathrm{N}}}{\sqrt{\left\{\sum \boldsymbol{x}^{2}-\frac{\left(\sum x\right)^{2}}{N}\right\}\left\{\sum y^{2}-\frac{\left(\sum y^{2}\right.}{N}\right\}}}
$$

Keterangan :

$\mathrm{x}$ : variabel $\mathrm{x}$

$\mathrm{y}$ : variabel y

$\mathrm{N}$ : jumlah

$\mathrm{r}_{\mathrm{xy}}:$ product moment

\section{b. Uji t (Uji Parsial)}

Uji t digunakan untuk menguji bagaimana hubungan masing-masing variabel bebasnya secara sendiri-sendiri terhadap variabel terikatnya. Uji ini dilakukan dengan membandingkan $t_{\text {hitung }}$ dengan $t_{\text {tabel. }}$.

Uji $t_{\text {hitung }}: \frac{r \sqrt{n-2}}{\sqrt{1-(r)^{2}}}$

\section{c. Koefisien Determinasi}

Koefisien determinasi (KD) adalah angka yang menyatakan atau digunakan untuk mengetahui konstribusi atau sumbangan yang diberikan oleh sebuah variabel atau lebih $\mathrm{X}$ (bebas) terhadap variabel $\mathrm{Y}$ (terikat).

Rumus : KD $=r^{2} \times 100 \%$

Keterangan :

KD : Koefisien Determinasi

$\mathrm{r}^{2} \quad$ : koefisien korelasi

\section{Hasil Penelitian dan Pembahasan}

Penelitian ini bertujuan untuk mengetahui apakah ada hubungan yang positif antara kompetensi guru terhadap prestasi belajar siswa SMP Negeri 3 Takkalalla kabupaten Wajo. Dalam penelitian ini melaporkan hasil penelitian yang telah dilakukan pada tanggal 11 - 12 Mei 2018. Pengambilan data dilakukan dengan menggunakan angket dan dokumentasi. Hasil pada penelitian ini disajikan dalam dua bentuk analisis statistik yaitu analisis deskriptif dan analisis inferensial. Analisis deskriptif adalah suatu teknik analisis yang bertujuan untuk menggambarkan keadaan sampel penelitian, sedangkan analisis statistik inferensial adalah suatu teknik analisis yang bertujuan untuk pengujian hipotesis 
penelitian. Untuk lebih lengkapnya berikut ini analisis variabel-variabel penelitian yang diteliti.

\section{Analisis Statistik Deskriptif}

a. Kompetensi Guru di SMP Negeri 3 Takkalalla

Data kompetensi guru diperoleh dari angket. Sebelum siswa mengisi angket peneliti memberikan arahan petunjuk pengisian angket. Angket yang digunakan dalam penelitian ini sudah divalidasi oleh pembimbing. Angket yang telah divalidasi tersebut kemudian disebar pada sampel penelitian yang berjumlah 80 orang siswa. Skor yang digunakan dalam penelitian ini adalah 4, 3, 2 dan 1.

Setelah angket diisi oleh 80 orang siswa, peneliti membuat distribusi skor jawaban, kemudian menentukan skor jawaban sesuai dengan ketentuan skor yang telah ditetapkan. Skor jawaban dari masing-masing responden kemudian ditabulasi (lampiran 2). Skor tertinggi diperoleh 124 dan skor terendah 31, dengan nilai mean 77,5 dan standar deviasi 15,5 (lampiran 4).

Dari nilai mean dan standar deviasi dapat dilakukan klasifikasi mengenai tingkat kompetensi guru. Klasifikasi kompetensi guru tersebut dapat dilihat pada tabel di bawah ini.

Tabel 4.1 Klasifikasi Kompetensi Guru

\begin{tabular}{llll}
\hline Skor Skala & Frekuensi & Presentase & Kategori \\
\hline $\mathrm{X}<62$ & 0 & 0 & Rendah \\
$62 \leq \mathrm{X}<93$ & 0 & 0 & Sedang \\
$93<\mathrm{X} 124$ & 80 & $100 \%$ & Tinggi \\
\hline
\end{tabular}

Sumber : SMP Negeri 3 Takkalalla Tahun Pelajaran 2017/2018

Dari tabel di atas dapat dilihat bahwa kompetensi guru berada pada interval $93 \leq \mathrm{X}<124$ (lampiran 4) karena siswa yang menjawab angket kompetensi guru sebanyak 80 siswa (100\%). Jadi dapat disimpulkan bahwa kompetensi guru termasuk dalam kategori tinggi.

b. Prestasi Belajar Siswa SMP Negeri 3 Takkalalla

Nilai prestasi belajar siswa SMP Negeri 3 Takkalalla kabupaten Wajo selengkapnya disajikan pada lampiran 3, maka statistik skor nilai prestasi belajar siswa disajikan pada tabel berikut.

Tabel 4.2 Distribusi dan Presentasi Skor Prestasi Belajar

\begin{tabular}{llcc}
\hline \multicolumn{1}{c}{ Skor } & \multicolumn{1}{c}{ Kategori } & Frekuensi & Presentase \\
\hline $81-100$ & Sangat Tinggi & 80 & $100 \%$ \\
$61-80$ & Tinggi & 0 & 0 \\
$41-60$ & Sedang & 0 & 0 \\
$21-40$ & Rendah & 0 & 0 \\
$0-20$ & Sangat Rendah & 0 & 0 \\
\hline & Jumlah & & $100 \%$ \\
\hline
\end{tabular}

Sumber : SMP Negeri 3 Takkalalla Tahun Pelajaran 2017/2018

Dari tabel di atas dapat dilihat bahwa prestasi belajar siswa SMP Negeri 3 Takkalalla kabupaten Wajo dikategorikan sangat tinggi. Hal ini terlihat bahwa 80 siswa yang dijadikan responden memiliki nilai antara 81-100 . 


\section{Uji Prasyarat Analisis}

a. Uji Normalitas

Uji normalitas digunakan untuk mengetahui apakah data dalam penelitian berdistribusi normal atau tidak. Pada penelitian ini normalitas dilakukan pada kedua variabel yang akan diteliti menggunakan uji Kolmogrof-Smirnov dengan bantuan SPSS 24 (perhitungan terlampir pada lampiran 6). Pada ketentuan pengujian dengan taraf signifikan $5 \%$.

Berdasarkan hasil perhitungan tersebut dapat diketahui bahwa nilai sig $0,99>0,05$ sehingga dapat disimpulkan bahwa data variabel kompetensi guru dan prestasi belajar berdistribusi normal.

b. Uji Linearitas

Uji linearitas digunakan untuk mengetahui apakah ada hubungan antara setiap variabel bebas dan variabel terikat dalam penelitian bersifat linier atau tidak secara signifikan. Pada penelitian ini uji linearitas dilakukan dengan bantuan SPSS 24 (perhitungan terlampir pada lampiran 6). Pada ketentuan pengujian dengan taraf signifikansi $5 \%$.

Berdasarkan hasil perhitungan tersebut diketahui bahwa nilai signifikansi $0,367>0,05$ sehingga dapat disimpulkan bahwa data variabel terdapat hubungan linear antara variabel.

\section{Analisis Statistik Inferensial}

Analisis statistik inferensial digunakan untuk pengujian hipotesis penelitian. Pada penelitian ini digunakan analisis Korelasi Product Moment. Pada penelitian ini uji hipotesis dilakukan dengan bantuan SPSS 24.

Tabel 4.3 Hasil Uji Korelasi menggunakan SPSS Correlations

\begin{tabular}{|ll|r|r|}
\hline & & Kompetensi Guru & \multicolumn{2}{|c|}{ Prestasi Belajar } \\
\hline Kompetensi Guru & Pearson Correlation & 1 &,- 282 \\
& Sig. (2-tailed) & &, 011 \\
& $\mathrm{~N}$ & 80 & 80 \\
\hline Prestasi Belajar & Pearson Correlation &,- 282 & 1 \\
& Sig. (2-tailed) &, 011 & \\
& $\mathrm{~N}$ & 80 & 80 \\
\hline
\end{tabular}

*. Correlation is significant at the 0.05 level (2-tailed).

Berdasarkan hasil perhitungan dengan bantuan SPSS tersebut diketahui bahwa :

Nilai $r=-0,282$

$$
\begin{aligned}
\text { Nilai } t_{\text {hitung }} & =\frac{r \sqrt{n-2}}{\sqrt{1-(r)^{2}}} \\
& =\frac{-0,282 \sqrt{80-2}}{\sqrt{1-(-0,282)^{2}}} \\
& =\frac{-0,282 \sqrt{78}}{\sqrt{1-(0,07)}} \\
& =\frac{-0,282 \times 8,83}{\sqrt{0,93}}
\end{aligned}
$$




$$
\begin{aligned}
& =\frac{-2,49}{0,96} \\
& =-2,59 \\
\text { Nilai } t_{\text {tabel }} & =1,99085
\end{aligned}
$$

Berdasarkan hasil analisis di atas, diperoleh nilai $t_{\text {hitung }}$ sebesar $-2,59$. Kemudian untuk mengetahui apakah hubungan tersebut signifikan atau tidak adalah dengan membandingkan nilai $t_{\text {hitung }}$ dengan $t_{\text {tabel }}$ pada taraf signifikan $5 \%$ dan $\mathrm{N}=80$ didapatkan 1,99085. Analisis korelasi dilanjutkan dengan menghitung koefisien determinasi, dengan cara mengkuadratkan koefisien yang ditemukan. Jadi koefisien terminasinya adalah $-0,282^{2}$ x $100 \%=0,07$.

\section{Pembahasan}

Penelitian ini bertujuan untuk mengetahui hubungan kompetensi guru terhadap prestasi belajar siswa SMP Negeri 3 Takkalalla kabupaten Wajo. Pengambilan data dilakukan dengan angket dan dokumentasi. Angket digunakan untuk mengetahui kompetensi guru sedangkan dokumentasi digunakan untuk mengetahui prestasi belajar siswa SMP Negeri 3 Takkalalla Kabupaten Wajo.

Kompetensi guru adalah kemampuan yang harus dimiliki guru dari tingkat prasekolah, tingkat dasar, dan tingkat menengah sesuai dengan jenjang dan jenis pendidikan yang ditekuni. Guru adalah seorang yang berprofesi sebagai seorang pengajar yang didapat melalui jenjang pendidikan keguruan. Prestasi belajar adalah taraf keberhasilan siswa dalam mempelajari materi pelajaran di sekolah yang dinyatakan dalam bentuk skor yang diperoleh dari hasil tes mengenai sejumlah materi pelajaran tertentu. Sedangkan dalam Kamus Besar Bahasa Indonesia, bahwa yang dimaksud dengan prestasi belajar adalah pengusaan pengetahuan atau keterampilan yang dikembangkan oleh mata pelajaran, lazimnya ditunjukkan dengan nilai tes atau angka yang diperoleh oleh guru.

Terdapat banyak faktor yang mempengaruhi prestasi belajar siswa seperti yang sudah dijelaskan pada tinjauan pustaka. Sehubungan dengan masalah ini, penulis sengaja mengutip pendapat Gunarsa (1990: 48) tentang faktor-faktor yang mempengaruhi proses belajar anak di sekolah yaitu: “(1) seseorang (pribadi); (2) bahan yang dipelajari; (3) cara-cara belajar".

Pengetahuan dan pemahaman yang mendalam mengenai indikator prestasi belajar sangat diperlukan ketika seseorang akan menggunakan alat dan kiat evaluasi. Muhibbin (2008: 150) mengemukakan bahwa urgensi pengetahuan dan pemahaman yang mendalam mengenai jenis-jenis prestasi belajar dan indikator-indikatornya adalah bahwa pemilihan dan pengunaan alat evaluasi akan menjadi lebih tepat, reliabel, dan valid.

Berdasarkan hasil analisis korelasi product momen, hubungan kompetensi guru terhadap prestasi belajar siswa SMP Negeri 3 Takkalalla kabupaten Wajo diperoleh nilai $t_{\text {hitung }}$ sebesar -2,59. Sedangkan $t_{\text {tabel }}$ sebesar 1,99085 pada taraf signifikan $5 \%$ dan $\mathrm{N}=80$. Dari hasil analisis tersebut terlihat bahwa nilai $t_{\text {hitung }}<t_{\text {tabel }}(-2,59<1,99085)$. Berdasarkan analisis tersebut dapat disimpulkan bahwa tidak ada hubungan antara kompetensi guru terhadap prestasi belajar siswa SMP Negeri 3 Takkalalla kabupaten Wajo Tahun Pelajaran 
$2017 / 2018$.

Hal ini sejalan dengan penelitian yang pernah dilakukan oleh Muhlis (2016) dalam skripsinya yang berjudul "Pengaruh Kompetensi Guru Terhadap Prestasi Belajar Siswa Kelas IV MI Bahrul Ulum Bontorea Kabupaten Gowa". Hasil penelitian tersebut menunjukkan bahwa tidak ada pengaruh yang signifikan antara Kompetensi Guru Terhadap Prestasi Belajar Siswa Kelas IV MI Bahrul Ulum Bontorea Kabupaten Gowa.

Selain itu, penelitian yang dilakukan oleh Musniyati Sakinah (2017) dalam skripsinya yang berjudul "Hubungan Profesionalisme Guru dengan Hasil Belajar Siswa Kelas IV SD Negeri 10 Metro Timur". Hasil penelitian itu juga menunjukkan bahwa tidak ada hubungan yang signifikan antara Profesionalisme Guru dengan Hasil Belajar Siswa Kelas IV SD Negeri 10 Metro Timur.

\section{Daftar Pustaka}

Arikunto, Suharsimi. 1993). Manajemen Pengajaran Secara Manusiawi, Jakarta: Rineka Cipta

Azwar,Saifuddin. 2007. Metode Penelitian. Yogyakarta: Pustaka Pelajar.

Dimyati, 2006. Belajar dan Pembelajaran, Jakarta : Rineka Cipta.

Djaali, 2007. Psikologi Pendidikan, Jakarta : Bumi Aksara.

Hakim, Lukmanul. 2009. Perencanaan Pembelajaran. Bandung : Wacana Prima

Hamzah B.Uno, 2007. Profesi Kependidikan Problema, Solusi dan Reformasi Pendidikan di Indonesia, Jakarta : Bumi Aksara

Heruman, 2010. Model Pembelajaran di Sekolah Dasar, Bandung : Remaja Rosdakarya.

Hudojo, Herman. 2001. Pengembangan Kurikulum dan Pembelajaran, Malang : Universitas Negara Malang.

Jannah, Raodatul. 2011. Membuat Anak Cinta dan Eskak Lainnya, Jogjakarta : Diva Press.

Mulyasa, E. 2007. Standar Kompetensi dan Sertifikasi Guru, Bandung : Remaja Rosdakarya.

Mulyasa, 2011. Menjadi Guru Profesional, Bandung : Remaja Rosdakarya.

Naim, Ngainun. 2011. Menjadi Guru Inspiratif, Jogyakarta : Pustaka Pelajar.

Riduwan, 2014. Metode dan Teknik Menyusun Proposal Penelitian. Bandung : Alfabeta

Singgih D. Gunarsa. 1990. Psikologi Perkembangan, Jakarta : BPK Gunung Mulia.

Sugiyono. 2012. Memahami Penelitian Kualitatif. Bandung: Alfabeta

Sugiyono. 2013. Statistik untuk Penelitian, Bandung : Alfabeta 
Surya, Muhammad. 2003. Pengantar Teori Konseling. Bandung : Pustaka Bani Syah, Muhibbin. 2008. Psikologi Belajar, Jakarta : Rajawali Perss.

Tilaar, 2002. Membenahi Pendidikan Nasional, Jakarta : PT Rineka Cipta

Usman, Uzer. 2008. Menjadi Guru Profesional, Bandung : Remaja Rosdakarya. https://marlina2.wordpress.com/2011/03/31/indikator-prestasi-belajar/. Diakses pada tanggal 13 Februari 2018 pukul $22.30 \mathrm{Wib}$

https://www.google.co.id/amp/s/jazzyla.wordpress.com/2010/04/15/kompetensi -guru/amp/ Diakses pada tanggal 8 Maret 2018 pukul 15.00 Wita

https://www.google.co.id/amp/s/exiaprasetya.wordpress.com/2010/05/12/empat -kompetensi-dasar-guru/amp/ Diakses pada tanggal 8 Maret 2018 pukul 15.15 Wita 